\title{
Seed Analysis and Seedling Production of Matayba elaeagnoides Radlk
}

\author{
Daniele Rorato ${ }^{1}$, Maristela Araujo ${ }^{1}$, Adriana Dutra ${ }^{1}$, Felipe Turchetto ${ }^{1}$, \\ Luciane Tabaldi ${ }^{1}$, Patrícia Mieth ${ }^{1}$
}

${ }^{1}$ Universidade Federal de Santa Maria - UFSM, Santa Maria/RS, Brasil

\begin{abstract}
The objective of this study was to evaluate the germination potential of Matayba elaeagnoides seeds, identifying the best substrate for laboratory analysis and to determine seedling emergence and growth under different shade levels in the nursery. Different substrates (paper roll, between and on blotting paper, and on sand or vermiculite) were evaluated in the germination test and different shade levels $(0,30,50$ and $75 \%)$ were tested in the nursery. No differences were found between the substrates for seed germination, however, the highest germination percentage was observed when using paper roll (70\%). The 30,50 and $75 \%$ shading intensities positively influenced Matayba elaegnoides seedling emergence, however, the best performance in nursery growth was observed under $75 \%$ shade presenting seedlings with better standard and quality.
\end{abstract}

Keywords: Matayba elaeagnoides (camboatá-branco), germination, shading. 


\section{INTRODUCTION AND OBJECTIVES}

Field studies for seed technology follow the recommendations found in the Rules for Seed Analysis (Regras para Análise de Sementes - RAS), which primarily include species of agronomic interest, but containing little information specifically for native forest species (Brasil, 2009). In this context, standardization regarding the germination of some forest species in the southern region of Brazil was proposed by Wielewicki et al. (2006). Additionally, a document supplementary to the RAS was prepared in 2013, addressing the particularities of 319 native and exotic forest species (Brasil, 2013). However, only 50 of these species had their evaluation methods validated by official laboratories of the Ministry of Agriculture, Livestock and Supply.

Seed germination is a complex process influenced by internal seed conditions and the management practices applied, in addition to environmental factors (Marcos, 2005). Among the environmental factors, germination will only occur under adequate moisture (water availability), temperature and oxygen conditions (Marcos, 2005; Carvalho \& Nakagawa, 2012). Therefore, understanding these factors is extremely important as it allows them to be controlled and managed to optimize the percentage, speed and uniformity of germination, thereby allowing us to determine the actual performance of the lot, as well as to provide information to standardize these tests for forest species (Nassif et al., 1998).

In order for germination to occur, the use of a suitable substrate is necessary, in addition to controlling all the factors mentioned above (Cetnarski \& Carvalho, 2009). In choosing the substrate to be used, species characteristics such as seed size, water requirements, photoblastism and the ease for development and seedling evaluation needs to be considered (Figliolia et al., 1993), as well as substrate characteristics such as composition, water retention capacity, porous structure, $\mathrm{pH}$, microbiological purity, resistance, toxicity, size and texture, which vary from one material to another (Brasil, 2009).

Additionally, light can be considered one of the environmental factors that exerts greatest influence on plant growth and development (Cancian \& Cordeiro, 1998), which as observed by Kozlowski et al. (1991), may be related to the ability to adapt to ambient light conditions. Understanding seed light requirements is of great importance for seedling production, since rapid and uniform seed germination will ensure that seedlings spend less time in vulnerable environmental conditions (Martins et al., 2009), as they mainly depend on the seed reserves. Therefore, characterizing the silvicultural behavior of native species according to the germination process and seedling growth in the nursery is of paramount importance for seed and seedling commercialization, especially given the increasing demand.

The Matayba elaeagnoides Radlk. (Sapindaceae) species is commonly known as camboatá-branco, and occurs naturally in Brazil between Mato Grosso and Rio Grande do Sul (Lorenzi, 2002; Carvalho, 2006). In relation to its successional group, it is classified as an initial secondary (Salis et al., 1994). It has timber, medicinal, landscaping and ecological potential, and is recommended for forest recovery (Backes \& Irgang, 2009), including in riparian environments.

Despite its importance, there is little silvicultural information for the species and it is not included in the RAS (Brasil, 2009), nor in the Instruction for Analysis of Forest Seeds (Brasil, 2013). Therefore, the objective of this study was to identify its appropriate substrate for germination, as well as to characterize the emergence and growth of Matayba elaeagnoides Radlk. seedlings under different shade intensities in the nursery.

\section{MATERIAL AND METHODS}

\subsection{Study site and fruit collection}

Ripe Matayba elaeagnoides fruit were collected from eight trees situated in Val Feltrina, Silveira Martins, RS, and then taken to the Forestry Laboratory and Forest Nursery of the Forest Sciences department of the Federal University of Santa Maria (UFSM), Santa Maria, RS. There, fruit processing was carried out by removing the aril that surrounds the seed, as recommended by Carvalho (2006), in addition to seed analysis and seedling production.

The climate of the region is type "Cfa", subtropical humid, with rains all year round, with an average annual precipitation of $1.620 \mathrm{~mm}$, average temperature in the hottest month exceeding $22^{\circ} \mathrm{C}$, and between -3 and $18^{\circ} \mathrm{C}$ in the coldest month (Alvares et al., 2013). 


\subsection{Seed storage and germination test}

Matayba elaegnoides seeds were stored in polyethylene bags in a cold room (relative humidity of $80 \%$ and temperature of $8^{\circ} \mathrm{C}$ ), remaining in this condition for 42 days. Immediately after this period, the weight of one thousand seeds and water content seeds were determined based on the recommendations of the RAS (Brasil, 2009).

In addition, a germination test was carried out using five substrate types: paper roll (PR), between blotting paper (BBP), on blotting paper (OBP), on sand (OS) and on vermiculite (OV). Three "Germitest" paper sheets were used for the PR substrate, while two sheets and one sheet, respectively, were used for BBP and OBP, which were moistened to 2.5 times the paper's weight. Regarding the sand (sieved in $0.84 \mathrm{~mm}$ mesh) and vermiculite (fine granulometry) substrates, both were moistened to $60 \%$ of their water retention capacity.

Before the germination test was installed, the seeds were immersed for twelve hours in sterile distilled water at room temperature. Seed disinfestation was subsequently carried out by immersion in $2 \%$ sodium hypochlorite solution for 3 minutes, followed by rinsing in distilled and sterilized water.

The test was conducted in a Mangelsdorf germinating chamber under constant light and a temperature of $25^{\circ} \mathrm{C} \pm 2{ }^{\circ} \mathrm{C}$, using a completely randomized experimental design, with four replicates of 25 seeds each. Counts were performed every three days to obtain the percentage of normal (NS), abnormal (AS), and at the end, the number of non-germinated seeds were classified as dead seeds (DS) or firm seeds (FS). Classification of seedlings (NS and AS) and seeds (DS and FS) was performed according to Brasil (2009). Based on the observations, it was possible to determine the germination (NS\%), Germination Speed Index (GSI) (Maguire, 1962) and Average Germination Time (AGT) (Labouriau, 1983).

\subsection{Production of seedlings in nursery}

At 65 days after collection, the stored seeds were submitted to the same pre-germination treatment as the germination test (12 hours of imbibition) to evaluate the emergence of seedlings and seedling growth.

Sowing was carried out in polypropylene conical tubes $\left(110 \mathrm{~cm}^{3}\right.$ capacity), which were placed in plastic trays, and filled with commercial substrate (composed of Sphagnum peat, expanded vermiculite, dolomitic limestone, agricultural gypsum and NPK fertilizer) mixed in carbonized rice husk (CRH) at a proportion of 3:2 (v:v). Each tube received two seeds for subsequent thinning, leaving only the most vigorous and central seedling.

Basic fertilization was added to the substrate using a controlled release fertilizer (CRF) (NPK 18-05-09) at a dosage of $5 \mathrm{~g} \mathrm{~L}^{-1}$ of substrate. Surface fertilization was applied in the second month using NPK (9-45-15), in addition to the micronutrients Boron and Zinc at a dose of 3 g. $\mathrm{L}^{-1}$, applied weekly.

\subsubsection{Seedling emergence}

After sowing, the plastic trays containing the tubes were taken into the greenhouse where they remained under shading hoods (a structural part made of $25 \mathrm{~mm}$ PVC pipes, covered with shading screens of different intensities) for a period of 90 days. The experimental design was completely randomized, and included four levels of shade intensity ( 0 - complete sun exposure, 30,50 and $75 \%$ ), with five replications of 25 seedlings each. A seedling emergence count was performed every three days, allowing for determining the percentage of Emergence (E), Emergence Speed Index (ESI) (Maguire, 1962) and Average Emergence Time (AET) (Labouriau, 1983).

\subsubsection{Seedling growth}

After the period in the greenhouse (90 days), the seedlings were taken to the growth area (open area, under complete sun exposure), using the same shading chamfers mentioned above. They remained in this condition for 510 days. The experimental design used was randomized blocks, adopting five blocks with 25 sample units (seedlings) per treatment. Different levels of shading intensity were tested ( 0 - complete sun exposure, 30,50 and $75 \%$ ), conducted in a $4 \times 9$ factorial scheme (four shading intensities $\mathrm{x}$ nine evaluation times). The parameters determined were: height in $\mathrm{cm}(\mathrm{H})$, stem diameter in $\mathrm{mm}(\mathrm{SD})$ and $\mathrm{H} / \mathrm{SD}$ ratio of the seedlings. In the last measurement, destructive analyses were complementarily performed, to determine specific leaf area (SLA), shoot dry weight (SDW), root dry weight (RDW) and Dickson Quality Index (DQI).

$\mathrm{H}$ and $\mathrm{SD}$ of the seedlings were measured with a graduated ruler and a digital caliper, respectively, every 60 days, considering five central plants per replicate, 
thereby avoiding the border effect. For SLA, three seedlings from each treatment were used, and after separation of the aerial part with the aid of pruning shears, the leaves were distributed over white paper and then covered by transparent glass for fixation. The samples were photographed using a Sony DSC T-100 digital camera, and a millimeter ruler was used for measurement. The images were processed with the help of the IrfanView ${ }^{\circledR}$ and IrfanView Thumbnails ${ }^{\circledR}$ programs.

The aerial part and the roots of three seedlings were used for SDW and RDW analysis, respectively, separated with the aid of pruning shears, with the samples kept in a forced circulation air oven for 72 hours at $70^{\circ} \mathrm{C}$. Based on this information, it was possible to obtain the Dickson Quality Index (DQI) calculated according to the following formula: TDW $(\mathrm{g}) /[\mathrm{H}(\mathrm{cm}) / \mathrm{SD}(\mathrm{mm})+$ SDW (g)/RDW (g)] (Dickson et al., 1960).

\subsection{Statistical analysis}

Data were submitted to statistical assumption analyses, with the Shapiro-Wilk test being used to verify the normality of residues, while the Bartlett test was used to check homogeneity between variances. When-the assumptions of normality and homogeneity were not met, the data were submitted to the non-parametric Kruskal-Wallis test to verify the existence of differences between treatments. Moreover, the mean point/midpoint measurement $(\mathrm{Mp})$ of these variables was compared by the Dunn Test (Callegari-Jacques, 2003) when necessary.

The comparison of means after the analysis of variance was performed by the Tukey test at 5\% probability of error, and regression analysis was performed for when $\mathrm{H}$ and SD were analyzed over time. Data were processed using SISVAR software (Ferreira, 2011).

\section{RESULTS AND DISCUSSION}

\subsection{Seed analysis}

One thousand Matayba elaeagnoides seeds presented a weight of $260.4 \mathrm{~g}$, resulting in $3.840 \mathrm{~kg}^{-1}$ seeds, and a water content of $51.65 \%$. Lorenzi (2002) described $3.250 \mathrm{~kg}^{-1}$ seeds for the same species, demonstrating morphological variation in the seeds of this species. This can be justified by the edaphoclimatic variations existing in the different physiographic regions where the seeds can be collected, which results in morphological differences. Furthermore, Cetnarski \& Nogueira (2005) reported that the age of the matrices and water content of the seeds are also determinant factors for the variations among different species.

Matayba elaeagnoides seed germination can be considered slow (mean AGT of 40.5 days), starting on the $31^{\text {st }}$ day after the test, with evaluations being conducted up to 43 days after their installation. This indicates that Matayba elaeagnoides seedlings may be more vulnerable to environmental conditions due to slow germination and spending longer in the initial developmental stages. Seed germination did not show significant differences between the substrates for any analyzed variable (Table 1).

The average germination (NS) was $64 \%$, obtaining a higher percentage for NS (70\%) and GSI value (0.36) for the paper roll (PR) substrate. Corroborating this result

Table 1. Percentage of normal seedlings (NS), abnormal seedlings (AS), firm seeds (FS), dead seeds (DS), Germination Speed Index (GSI) and Average Germination Time (AGT) of Matayba elaeagnoides.

\begin{tabular}{|c|c|c|c|c|c|c|}
\hline Treatment & $\mathbf{N S}^{*}$ & $\mathbf{A S}^{\star *}$ & FS $^{*}$ & $\mathrm{DS}^{* *}$ & GSI* $^{*}$ & AGT* \\
\hline PR & $70.00 \mathrm{a}$ & $5.00 \mathrm{a}$ & $13.75 \mathrm{a}$ & $11.25 \mathrm{a}$ & $0.36 \mathrm{a}$ & $39.50 \mathrm{a}$ \\
\hline BBP & $67.50 \mathrm{a}$ & $8.75 \mathrm{a}$ & $3.75 \mathrm{a}$ & $20.00 \mathrm{a}$ & $0.33 \mathrm{a}$ & $41.75 \mathrm{a}$ \\
\hline OBP & $68.75 \mathrm{a}$ & $0.00 \mathrm{a}$ & $13.75 \mathrm{a}$ & $17.50 \mathrm{a}$ & $0.35 \mathrm{a}$ & $39.25 \mathrm{a}$ \\
\hline OS & $50.00 \mathrm{a}$ & $3.75 \mathrm{a}$ & $10.00 \mathrm{a}$ & $36.25 \mathrm{a}$ & $0.34 \mathrm{a}$ & $41.10 \mathrm{a}$ \\
\hline $\mathrm{OV}$ & $65.00 \mathrm{a}$ & $0.00 \mathrm{a}$ & $11.25 \mathrm{a}$ & $23.75 \mathrm{a}$ & $0.32 \mathrm{a}$ & $41.25 \mathrm{a}$ \\
\hline Mean & 64.25 & 3.50 & 10.50 & 21.75 & 0.34 & 40.57 \\
\hline $\mathrm{W}$ & 0.299 & $<0.0001 /<0.0001$ & 0.081 & $0.004 / 0.049$ & 0.478 & 0.084 \\
\hline$\chi^{2}$ & 0.321 & 0.943 & 0.460 & $0.046 / \mathbf{0 . 0 5 2}$ & 0.464 & 0.240 \\
\hline CV (\%) & 17.650 & 165.223 & 81.092 & 71.041 & 17.811 & 2.552 \\
\hline
\end{tabular}

Where: PR: paper roll; BBP: between blotting paper; OBP: on blotting paper; OS: on sand; OV: on vermiculite; W: Shapiro-Wilk test statistics; $\chi^{2}$ : Bartlett test statistics; CV: coefficient of variation. Values in bold indicate residue normality and homogeneity of variance, respectively, after data transformation. Averages followed by the same letter in the column do not differ from each other by the ${ }^{*}$ Tukey test and ${ }^{* *}$ Kruskal-Wallis test at $5 \%$ probability of error. 
in the Instruction for the Analysis of Matayba guianensis seeds (another species of the genus), PR is also recommended for the germination test (Brasil, 2013). This type of substrate presents low contamination by microorganisms, practicality for use and easy evaluation of seeds as positive aspects (Flores et al., 2014), with the last two also being observed in this study. The answer obtained from Matayba elaegnoides is also interesting to corroborate the description from Brasil (2013), which reports that recommendations for the species of the same genus should be followed in the absence of instructions for a particular species.

Additionally, the use of the paper roll brings a number of advantages such as the best development of essential seedling structures, allowing rapid and safe evaluation, adequate spacing between seedlings (Oliveira et al., 2008), and ease in implementing/conducting the test, as well as occupying less space in the germinator, thereby allowing for the simultaneous execution of a larger number of analyses (Lima \& Garcia, 1996).

On the other hand, the OS and OV substrates provided the lowest germination percentages of NS for Matayba elaegnoides (Table 1). By contrast to these results, Gasparin et al. (2012) in a study with Allophylus edulis (also from the Sapindaceae family), recommended the sand and vermiculite substrates for germination.

\subsection{Seedling emergence and growth}

Regarding E, ESI and AET as a function of shading, a significant difference was reported for the $\mathrm{E}$ and AET variables. Matayba elaeagnoides presented the highest E values when subjected to the shading intensities of 30,50 and $75 \%$, while AET was lower at $75 \%$ shading (Table 2) compared to complete sun exposure (0\%). Due to seedlings emerging faster under this shading condition (75\%), they are less vulnerable to unfavorable environmental conditions.

Similar ESI results were found by Vieira et al. (2008) with Cupania vernalis (Sapindaceae) seeds with $46 \%$ water content. The emergence of certain species may be inhibited or stimulated by exposure to light. In the case of the species under study, characterized as initial (Salis et al., 1994) to late secondary (Chami et al., 2011), it requires lower luminosity rates for its development. Therefore, shading levels of 30, 50 and 75\% favor seedling emergence. It is important to note that in the nursery environment, the AET was approximately half that obtained in the germination test, even with a constant temperature of $25^{\circ} \mathrm{C}$, which may be related to the constant light used in the laboratory.

The Matayba elaeagnoides seedlings presented growth variability in terms of height, only being influenced by the shading level factor (Figure 1), without presenting significant interaction between the shading level and evaluation periods.

Taller plants were observed with $75 \%$ shading, while the plants presented smaller sizes at lower intensities (Figure 1). The growth of shorter plants under complete sun exposure may indicate that this condition limits the development of this species. Moreover, the increase in plant height when grown in shaded areas is considered a typical morphogenic response (Smith \& Whitelam, 1990), since there is generally a rapid allocation of assimilates to the aerial part under these conditions, which gives the plant more

Table 2. Percentage of Emergence (E), Emergence Speed Index (ESI) and Average Emergence Time (AGT) of Matayba elaeagnoides seeds.

\begin{tabular}{|ccccc|}
\hline Shading & E $^{* *}$ & Mp E & ESI $^{*}$ & AET $^{*}$ \\
\hline $0 \%$ & 31.50 & $\mathrm{~B}$ & $0.77 \mathrm{a}$ & $22.40 \mathrm{~b}$ \\
\hline $30 \%$ & 63.00 & $\mathrm{~A}$ & $0.77 \mathrm{a}$ & $21.20 \mathrm{ab}$ \\
\hline $50 \%$ & 59.00 & $\mathrm{a}$ & $0.76 \mathrm{a}$ & $21.20 \mathrm{ab}$ \\
\hline $75 \%$ & 56.50 & $\mathrm{a}$ & $0.73 \mathrm{a}$ & $20.40 \mathrm{a}$ \\
\hline $\mathrm{W}$ & $0.0014 / 0.0014$ & & 0.1954 & 0.0569 \\
\hline$\chi^{2}$ & 0.1292 & & 0.9227 & 0.4462 \\
\hline $\mathrm{CV}(\%)$ & 4.5142 & & 7.3770 & 4.7532 \\
\hline
\end{tabular}

Where: W: Shapiro-Wilk test statistics; $\chi^{2}$ : Bartlett test statistics; CV: coefficient of variation. Averages followed by the same letter in the column do not differ from each other by the ${ }^{*}$ Tukey test nor the ${ }^{* *}$ comparison of the mean point/midpoint measurement (Mp) by the Dunn Test.

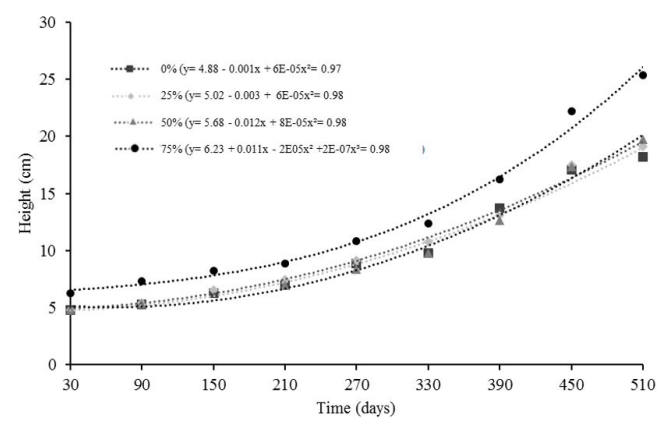

Figure 1. Height $(\mathrm{cm})$ of Matayba elaeagnoides seedlings for different shadings and evaluation periods. 
favorable exposure of its photosynthetic surface to the light (Queiroz \& Firmino, 2014).

The species showed a trend towards greater growth under $75 \%$ shading starting from the immediate phase up until the emergence phase (30 days), intensifying from 330 days (Figure 1). This fact clearly indicates two conditions: a) the species presents slow growth, possibly influenced by the seasonality of the Southern region; and b) there was higher carbon allocation for height growth in relation to other variables under higher shading.

Similar studies considering shading levels were performed by Lima et al. (2005) with Cupania vernalis. These authors recommended 50 or $70 \%$ shading for seedling production with this species in the nursery, which generated better quality seedlings.

Tolerance to low irradiance is a genetic feature that causes the leaves to exhibit anatomical structures and physiological properties, which enable them to effectively use available solar radiation (Larcher, 2000). Reduced height growth in complete sun exposure may be related to the elevation of temperature in the leaves, and thus to an intensification in the respiratory rate, which can indirectly induce stomata closure with a consequent reduction of carbon fixation, also causing an increase in the consumption of photoassimilates (Kozlowski et al.,
1991). Moreover, prolonged exposure to high irradiation may be detrimental to Matayba elaeagnoides seedlings that absorb more light photons than they can use, leading to photoinhibition of photosynthesis, and as a consequence, to a lower amount of fixed carbon and lower growth.

For growth of stem diameter (SD), no interaction between the shading level and evaluation periods was observed. For this attribute, only an isolated effect of both factors (Figure 2A and 2B) was found, in which $\mathrm{SD}$ decreased as shade intensity increased (Figure 2A). In addition, evidence of increased SD over time following increasing linear distribution (Figure 2B) was observed, indicating that the container condition was not limiting for seedling development, despite the extended period in the nursery, which is also confirmed by height (Figure 1).

The highest H/SD ratio, as well as SLA at 510 days, was found in the plants under $75 \%$ shading (Figure 3 ). $\mathrm{H} / \mathrm{SD}$ ratio presented no interaction between the shading level and evaluation periods, only being influenced by shading, which showed a tendency to decrease in plants cultivated under complete sun exposure ( $0 \%$ shading), while the highest values were obtained in seedlings grown under 75\% shading (Figure 3A). According to Gonçalves et al. (2005), good quality
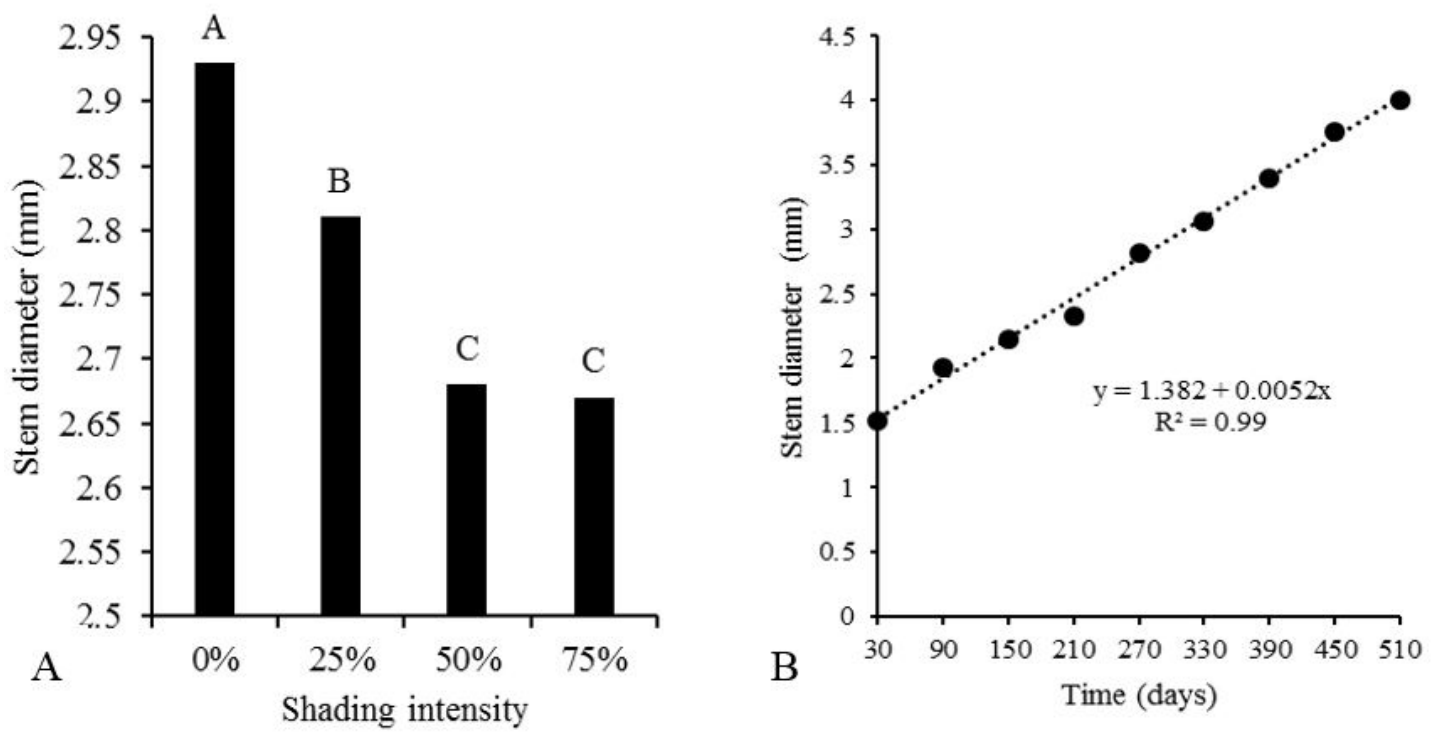

Figure 2. Stem diameter $(\mathrm{mm})$ of Matayba elaeagnoides seedlings for different shading levels (A) and different evaluation periods (B). (A) The letters A, B, C, indicate statistical difference by Tukey's test, at $5 \%$ error probability. 

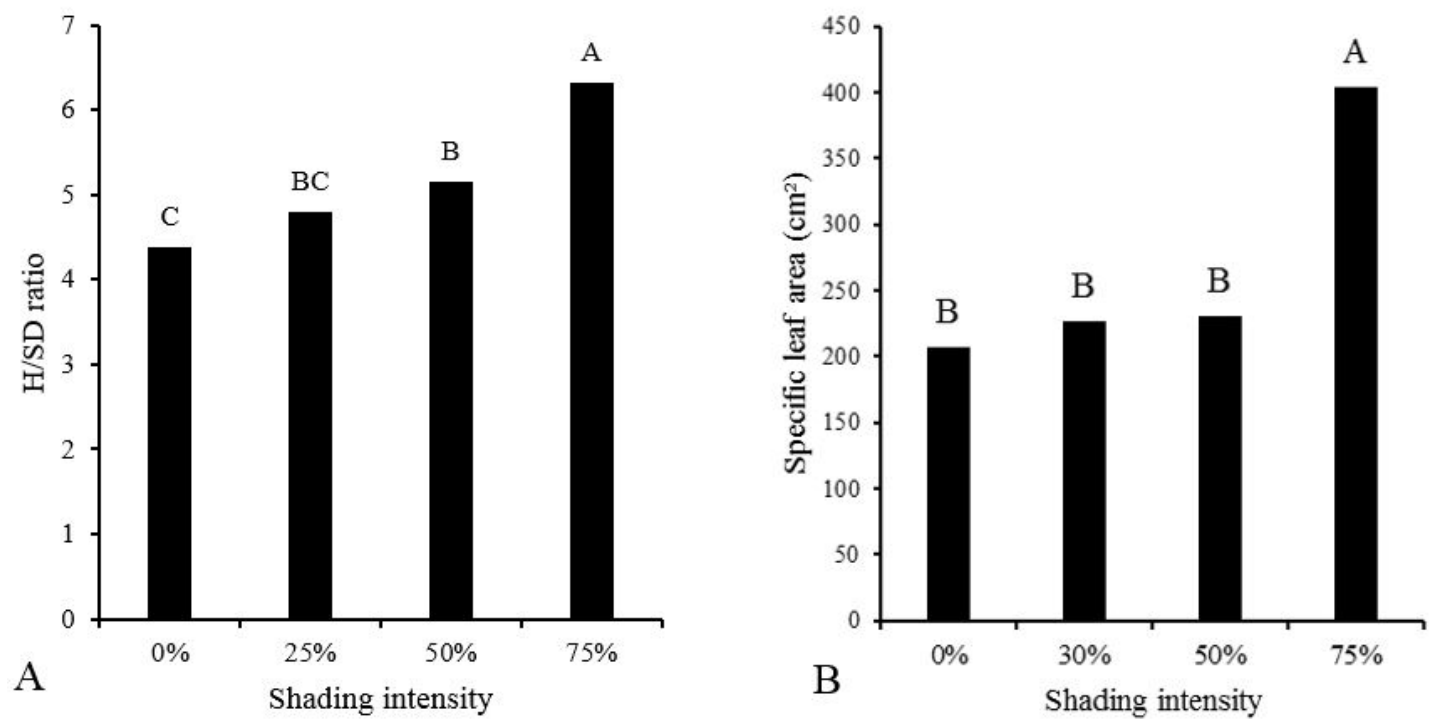

Figure 3. H/SD ratio (A) and specific leaf area $\left(\mathrm{cm}^{2}\right)(B)$ of Matayba elaeagnoides seedlings for different shading intensities. (A and B) The letters A, B or C, indicate statistical difference by Tukey's test, at 5\% error probability.

seedlings have values ranging from 2 to 7. Thus, all treatments presented values within the range; however, $75 \%$ shading obtained the highest value for the variable.

Plants under 75\% shading formed leaves with higher surface growth compared to those grown under 30 and $50 \%$ shading and complete sun exposure (Figure 3B), thus with higher SLA. Regarding total leaf area, several studies with arboreal species submitted to different irradiance levels under nursery conditions confirmed the results obtained with Matayba elaeagnoides (Lima et al., 2005; Lenhard et al., 2013). According to Lima et al. (2005), the increased leaf area with increasing shade is due to changes in epidermal and parenchymal cell thickness in order to compensate for the lower photosynthetic rates under shadier conditions, thus making better use of low light. Overall, we can highlight greater accumulation of chlorophyll in leaves exposed to higher shading levels (Taiz \& Zeiger, 2013), which provides an increase in biomass.

SDW and RDW presented behavior similar to the morphological variables $\mathrm{H}, \mathrm{H} / \mathrm{SD}$ and SLA, with higher values under $75 \%$ shading (Table 3). It is important to take into account that plants with a well-developed root system present better conditions established in the field, allowing for greater survival, greater ease for maintenance, and greater water and nutrient absorption rates by individuals. Portela et al. (2001) when analyzing
Table 3. Shoot dry weight (SDW) (g), root dry weight (RDW) (g) and Dickson Quality Index (DQI) of Matayba elaeagnoides seedlings.

\begin{tabular}{|clll|}
\hline Shading & SDW & RDW & DQI \\
\hline $0 \%$ & $2.13 \mathrm{c}$ & $2.38 \mathrm{~b}$ & $1.29 \mathrm{a}$ \\
\hline $30 \%$ & $2.81 \mathrm{c}$ & $2.84 \mathrm{ab}$ & $1.22 \mathrm{a}$ \\
\hline $50 \%$ & $4.56 \mathrm{~b}$ & $3.04 \mathrm{ab}$ & $1.42 \mathrm{a}$ \\
$75 \%$ & $6.87 \mathrm{a}$ & $4.57 \mathrm{a}$ & $1.61 \mathrm{a}$ \\
\hline $\mathrm{W}$ & 0.13711 & 0.05208 & 0.92402 \\
\hline$\chi^{2}$ & 2.25738 & 4.96470 & 5.29927 \\
\hline $\mathrm{CV}(\%)$ & 20.75 & 34.87 & 23.41 \\
\hline
\end{tabular}

Where: W: Shapiro-Wilk test statistics; $\chi^{2}$ Bartlett test statistics; $\mathrm{CV}$ : coefficient of variation. The averages followed by the same letter in the column do not differ by Tukey's test, at $5 \%$ error probability.

the initial growth of Clitoria fairchildiana R. A. Howard. and Peltophorum dubium (Spreng.) Taub. seedlings under different shading conditions $(0,30,50$ and $75 \%$ shading), corroborated these results, observing an influence on the height, increment in height, root length and dry matter root weight variables.

For DQI, there were no significant differences between treatments; however, the highest value was also obtained under $75 \%$ shading (Table 3 ). DQI is considered a good indicator of seedling quality, since the height, collection diameter and distribution balance of the biomass in the seedling are taken into account in its calculation (Fonseca et al., 2002). 
The analysis under $75 \%$ shading in which the lowest SD was associated with higher $\mathrm{H}$ and SLA, initially suggested the possibility of sowing the seedlings in this condition. However, the variable RDW mainly confirmed the superior quality of the seedlings produced under $75 \%$ shading, which was also the first treatment that reached the minimum standard for expedition ( $\mathrm{H}=15$ to $25 \mathrm{~cm} ; \mathrm{SD} \geq 2 \mathrm{~mm}$ ), as described by Wendling \& Dutra (2010).

However, it is evident that the species presents an ability to adapt to low-luminosity conditions, since it invests in the increase of SLA, which makes it possible to produce photoassimilates and increase RDW, confirming its late secondary characteristic in southern Brazil. Based on these results, it is also possible to verify that this species, under higher light intensity does not respond positively to H, SLA or SDW. Thus, seedling production and planting for this species under conditions of complete sun exposure should be avoided.

\section{CONCLUSION}

Matayba elaeagnoides germination is adequate for all tested substrates (paper roll, blotting paper, sand and vermiculite); however, the paper roll substrate stands out due to its practicality. The germination test can be concluded 43 days after implantation.

For seedling emergence, 30, 50 and 75\% shading are recommended. However, the best growth performance considering all variables analyzed was observed with $75 \%$ shading, with seedling development presenting a better standard and higher quality.

\section{SUBMISSION STATUS}

Received: 12 june, 2017

Accepted: 5 aug., 2017

\section{CORRESPONDENCE TO}

\section{Daniele Rorato}

Departamento de Ciências Florestais, Universidade Federal de Santa Maria - UFSM, Rua Silvio Feron, 1339, Centro, CEP 97230-000, São João do Polêsine, RS, Brasil e-mail: dannirorato@hotmail.com

\section{REFERENCES}

Alvares CA, Stape JL, Sentelhas PC, Gonçalves JLM, Sparovek G. Köppen's climate classification map for Brazil. Meteorologische Zeitschrift 2013; 22(6): 1-18.

Backes P, Irgang B. Árvores do sul: guia de identificação e interesse ecológico. Porto Alegre: Paisagem do Sul; 2009.

Brasil. Ministério da Agricultura, Pecuária e Abastecimento. Secretaria de Defesa Agropecuária. Regras para análises de sementes. Brasília: Mapa/ACS; 2009. 399 p.

Brasil. Ministério da Agricultura, Pecuária e Abastecimento. Secretaria de Defesa Agropecuária. Instruções para análise de espécies florestais. Brasília: Mapa/ACS; 2013.

Callegari-Jacques SM. Bioestatística: princípios e aplicações. Porto Alegre: Artmed; 2003.

Cancian MAE, Cordeiro L. Efeito do sombreamento no crescimento inicial de Lonchocarpus muehlbergianus Hassl. Acta Botanica Brasílica 1998; 12(3): 367-372. http://dx.doi. org/10.1590/S0102-33061998000400005.

Carvalho PER. Espécies Arbóreas Brasileiras. Brasília: Embrapa Informação Tecnológica; Colombo: Embrapa Florestas; 2006

Carvalho NM, Nakagawa J. Sementes: ciência, tecnologia e produção. 4. ed. Jaboticabal: Funep; 2012.

Cetnarski R Fo, Carvalho RIN. Massa da amostra, substrato e temperatura para teste de germinação de sementes de Eucalyptus dunni Maiden. Ciência Florestal 2009; 19(3): 257-265.

Cetnarski R Fo, Nogueira AC. Influência da temperatura na germinação de diásporos de Ocotea odorifera (Vellozo) Rohwer (canela-sassafrás). Ciência Florestal 2005; 15(2): 191-198. http://dx.doi.org/10.5902/198050981836.

Chami LB, Araujo MM, Longhi SJ, Kielse P, Lúcio AD. Mecanismos de regeneração natural em diferentes ambientes de remanescente de Floresta Ombrófila Mista, São Francisco de Paula, RS. Ciência Rural 2011; 41(2): 251-259. http:// dx.doi.org/10.1590/S0103-84782011000200012.

Dickson A, Leaf AL, Hosner JF. Quality appraisal of while spruce and white pine seedling stock in nurseries. Forestry Chronicle 1960; 36: 11-13.

Ferreira DF. Sisvar: a computer statistical analysis system. Ciência e Agrotecnologia 2011; 35(6): 1039-1042. http:// dx.doi.org/10.1590/S1413-70542011000600001.

Figliolia MB, Oliveira EC, Piña-Rodrigues FCM. Análise de sementes. In: Aguiar IB, Piña-Rodrigues FCM, Figliolia MB, editores. Sementes florestais tropicais. Brasília: Abrates; 1993. p. 137-174

Flores AV, Borges EEL, Gonçalves JFC, Guimarães VM, Ataíde GM, Barros DP et al. Efeito do substrato, cor e tamanho de sementes na germinação e vigor de Melanoxylon brauna. Pesquisa Florestal Brasileira 2014; 34(78): 141-147. http://dx.doi.org/10.4336/2014.pfb.34.78.558. 
Fonseca EP, Valéri SV, Miglioranza E, Fonseca NAN, Couto L. Padrão de qualidade de mudas de Trema micrantha (L.) Blume produzidas sob diferentes períodos de sombreamento. Revista Árvore 2002; 26(4): 515-523. http://dx.doi.org/10.1590/S0100-67622002000400015.

Gasparin E, Araujo MM, Ávila AL, Wielewicki AP. Identificação do substrato adequado para germinação de sementes de Allophylus edulis (A. St.-Hill., Cambess. \& A., Juss) Radlk. Ciência Florestal 2012; 22(3): 625-630. http://dx.doi.org/10.5902/198050986628.

Gonçalves JLM, Santarelli EG, Moraes SP No, Manara MP. Produção de mudas de espécies nativas: substrato, nutrição, sombreamento e fertilização. In: Gonçalves JLM, Benedetti V, editores. Nutrição e fertilização florestal. Piracicaba: IPEF; 2005. p. 309-350

Kozlowski TT, Kramer PJ, Pallardy SG. The physiological ecology of woody plants. Massachusetts: Academic Press; 1991.

Labouriau LG. A germinação das sementes. Washington: Secretaria Geral da Organização dos Estados Americanos; 1983.

Larcher W. Ecofisiologia vegetal. São Carlos: Rima; 2000.

Lenhard NR, Paiva VB, Scalon SPQ, Alvarenga AA. Crescimento de mudas de pau-ferro sob diferentes níveis de sombreamento. Pesquisa Agropecuária Tropical 2013; 43(2): 178-186. http://dx.doi.org/10.1590/S198340632013000200012 .

Lima D, Garcia LC. Avaliação de métodos para o teste de germinação em sementes de Acacia mangium Willd. Revista Brasileira de Sementes 1996; 18(2): 180-185. http:// dx.doi.org/10.17801/0101-3122/rbs.v18n2p180-185.

Lima EC Jr, Alvarenga AA, Castro EM, Vieira CV, Oliveira HM. Trocas gasosas, características das folhas e crescimento de plantas jovens de Cupania vernalis Camb. submetidas a diferentes níveis de sombreamento. Ciência Rural 2005; 35(5): 1092-1097. http://dx.doi.org/10.1590/ S0103-84782005000500016.

Lorenzi H. Árvores Brasileiras: Manual de Identificação e Cultivo de Plantas Arbóreas Nativas do Brasil. Nova Odessa: Plantarum; 2002.

Maguire JD. Speed of germination aid in selection and evaluation for seedling emergence and vigor. Crop Science 1962; 2(1): 176-177. http://dx.doi.org/10.2135/cropsci19 62.0011183X000200020033x.

Marcos J Fo. Fisiologia de sementes de plantas cultivadas. Piracicaba: Fealq; 2005
Martins CC, Bovi MLA, Spiering SH. Umedecimento do substrato na emergência e vigor de plântulas de pupunheira. Revista Brasileira de Fruticultura 2009; 31(1): 224-230. http://dx.doi.org/10.1590/S0100-29452009000100031.

Nassif SML, Vieira IG, Fernades GD. Fatores externos (ambientais) que influenciam na germinação de sementes. Informativo Sementes IPEF [online]. Abr 1998 [citado em 2017 Maio 25]. Disponivel em: http://www.ipef.br/ tecsementes/germinacao.asp

Oliveira LM, Davide AC, Carvalho MLM. Teste de germinação de sementes de Peltophorum dubium (Sprengel) Taubert - Fabaceae. Floresta 2008; 38(3): 545-551.http:// dx.doi.org/10.5380/rf.v38i3.12425

Portela RCQ, Silva IL, Piña-Rodrigues FCM. Crescimento inicial de mudas de Clitoria fairchildiana Howard e Peltophorum dubium (Spreng.) Taub. em diferentes condições de sombreamento. Ciência Florestal 2001; 11(2): 163-170. http://dx.doi.org/10.5902/198050981664.

Queiroz SEE, Firmino TO. Efeito do sombreamento na germinação e desenvolvimento de mudas de baru (Dipteryx alata Vog.). Revista Biociências 2014; 20(1): 72-77.

Salis MS, Tamashiro JY, Joly CA. Florística e fitossociologia do estrato-arbóreo de um remanescente de mata ciliar do Rio Jacaré- Pepira, Brotas, SP. Revista Brasileira de Botanica 1994; 17(2): 93-103.

Smith H, Whitelam GC. Phytochrome. A family of photoreceptors with ultiple physiological roles. Plant, Cell \& Environment 1990; 13(1): 695-707. http://dx.doi. org/10.1111/j.1365-3040.1990.tb01084.x.

Taiz L, Zeiger E. Fisiologia Vegetal. 5 ed. Porto Alegre: Artmed; 2013.

Vieira CV, Alvarenga AA, Castro EM, Nery FC, Santos MO. Germinação e armazenamento de sementes de camboatá (Cupania vernalis Cambess.) Sapindaceae. Ciência e Agrotecnologia 2008; 32(2): 444-448. http:// dx.doi.org/10.1590/S1413-70542008000200015.

Wendling I, Dutra LF. Produção de mudas de eucalipto por sementes. In: Wendling I, Dutra LF, editores. Produção de mudas de eucalipto. Colombo: Embrapa Florestas; 2010. p. 13-47.

Wielewicki AP, Leonhardt C, Schlindwein G, Medeiros ACS. Proposta de padrões de germinação e teor de água para sementes de algumas espécies florestais presentes na região sul do Brasil. Revista Brasileira de Sementes 2006; 28(3): 191-197. http://dx.doi.org/10.1590/S010131222006000300027 . 